\title{
The Experience of Assessing the Human Capital of Labor Ethnic Migration (Based on the Study of the Novosibirsk Region)
}

\author{
Natalia L. Mikidenko, \\ Tatiana I. Monastyrskaia and Svetlana P. Storozheva* \\ Siberian State University of Telecommunications \\ and Information Sciences \\ 86 Kirova Str., Novosibirsk, 630102, Russia
}

The need to assess the potential of labor migration is caused by the problems of effective management of incoming migration flows. The region that accepts labor migrants should be guided in the formation of their migration concept by their own economic tasks and needs. Contradictory assessments of migration processes are given in the works of Russian and foreign scientists, which is connected with the lack of an optimal model for calculating the economic feasibility of investing in labor migrants arriving in the territory of the region, as well as the model for assessing the human capital of migrants (cultural and social). One possible way of such an assessment can be based on the results of an analysis of the information needs of migrants. The study of labor migrants from Central Asia in the Novosibirsk region, aimed at identifying the essence and structure of the information needs of labor migrants, is an attempt to assess the potential of migrants in the human capital aspect. Awareness is considered as one of the elements of human capital that can be converted into an economic one, reducing time and money costs during the period of registration of documents, the search for housing and employment. Awareness is analyzed in terms of subjective assessment of the adequacy of information, possession of modern information services, access to the Internet, as well as the most sought-after sources when receiving information at home about the place of stay and upon arrival in the region.

Keywords: labor migration, ethnic migration, human capital, migration management, host community, awareness.

DOI: 10.17516/1997-1370-0143.

Research area: culturology.

\section{Introduction \\ to the research problem}

Labor migration is primarily related to the widening welfare gap between developed industrial countries and developing countries, an increase in the general level of awareness of population about the development of economy and migration policy in the countries that provide a high living wage for their citizens. As a result of migration processes, losses and acquisitions in different spheres of life are felt not only by the migrants themselves, but also by the countries

(C) Siberian Federal University. All rights reserved

* Corresponding author E-mail address: nl_nsk@mail.ru, t.monastyrskaya@ngs.ru, sv.stor@yandex.ru 
of the outcome of migrants, and by the host communities of countries of different continents, which experience a constant influx of labor resources from other ethnic communities.

In the EU countries the level of labor migration has increased significantly after the economic crisis of 2007. The main reason for labor migration in the countries of the European Commonwealth is structural imbalances, which are associated with the sharply differing capabilities of different countries to create jobs. The outflow of labor migrants from the peripheral southern regions to the central ones will have increasedup to 3.9 million people by 2020 (Sebald). Consequently, such a number of jobs should be provided in the countries of Central Europe, which in itself is already problematic. The structure of human capital of labor migrants from the southern regions of the EU is also changing. More and more people with higher education are trying to find a decent place to work (Peter). According to a study by Christian Cube in the United States, the pattern of labor migrants is as follows: a large proportion of migrant workers come from Mexico. Especially noticeable is the influx of migrants in the southern states of the United States, for example, in California. 27 million Mexicans residing in the United States make up $65 \%$ of the US population of Hispanic origin (Cube). With a constant influx of labor migrants from this country, it reduces the level of earnings, leads to unemployment in this part of the population, and, therefore, there is a threat that the social services should support the life of this group of people.

In Russia, a significant influx of labor migrants is observed from the countries of Central Asia, the former Republics of the USSR. Countries that lose their labor resources as a result of migration note the negative consequences of mass departure of citizens. Analysts refer "brain drain", that is, the retirement of qualified personnel from the production system of the stateto the negative consequences of migration for the human capital of Kyrgyzstan, which weakens the national innovation abilities, deforms the social and professional structure of the population as a result of a significant outflow of young people, determines the shortage of workers in the secondary technical professions, weakens the agrarian sector as a result of the departure of the rural population (Beishenaly, Pereboev, 2013: 83). The authors investigating the consequences of the outflow of labor migrants from Kyrgyzstan note that the return of labor migrants to Kyrgyzstan will have a positive effect on the development of the country's human capital through the arrival of specialists with new competencies and skills obtained in the countries of immigration (Consequences ...).

Concerns about the loss from labor migration are also expressed by the authorities of Uzbekistan. As measures to encourage return home, the authorities of Uzbekistan planned to create 409.5 thousand jobs in seven regions of the country in 2015 for those migrant workers who would want to return to their homeland. Returnees are offered work at their place of residence, or the opportunity to start their own business, support from the government and commercial banks, leasing unused public property, as well as land that is released as a result of demolition of unused facilities. When investing in such projects, it is planned to take into account the incomes received by migrants while working abroad (About 400,000 jobs...).

For Russia, the balance of inflow and outflow of the able-bodied population looks ambiguous. The study of V.I. Mukomel' contains data on the reduction of the able-bodied population of Russia over the past five years: thus, from 2012 to 2017 the able-bodied population has reduced by approximately 1 million people per year (Mukome'l, 2011:34), which certainly affects 
the country's economic development. According to the annual report on social policy of the National Research University Higher School of Economics titled Human Capital as a Factor of Social and Economic Development (April 2016), Russia will continue to reduce the able-bodied population until 2020, and from 2015 to 2027 the share of able-bodied population, despite the planned increase due to migration will decrease by 6.5 million people (Nelson, Phelps). In addition to the "aging population" trend, there is also an outflow of the able-bodied population in search of work in other countries. Labor migrants from Russia go mainly to the United States, Canada, European countries, Australia, young people also often choose New Zealand in the hope of a good job (Anokhina, Perevalova, 2013:39).

Thus, there arises the problem of assessing the human capital of labor migrants arriving in Russia, against the backdrop of the outflow of the able-bodied Russian population.

\section{Theoretical framework}

Modern migration research draws attention to micro-level aspects of migration behavior, as in modern societies socially organized forms of migration are replaced by "individualized" forms, and migration management becomes possible in terms of understanding the microeconomic foundations of this process, economic and noneconomic factors of migration behavior. One of such main concepts is the concept of human capital (Moiseenko, Chudinovskikh, 2000:135).

Initially, human capital was interpreted as a set of investments in a person that could increase his ability to work (education and professional skills). In the works of the followers of this theory, the concept of human capital changed, was supplemented and, as a result, was significantly expanded. For example, experts of the World Bank included consumer spending in the definition of human capital, including state expenditures on education, health care, culture, as well as family expenses for food, housing, clothes (Nesterov, Ashirova, 2003).

V.M. Moiseenko, O.S. Chudinovskikh emphasize that econometric models constructed on the basis of the theory of human capital allow one to estimate in monetary terms the set of factors that determine the consequences of migration for an individual (Moiseenko, Chudinovskikh, 2000:135). At the same time, the authors emphasize the possibility of using the theory of human capital for macro-level assessment, since migration and migration processes are associated with the processes of socio-economic development of society as a whole, and the territorial differentiation of this development and the concentration of economic growth and activity in key territories and sectors (Moiseenko, Chudinovskikh, 2000:125).

By the definition of I.A. Krutii and O.V. Krasina human capital is a set of skills, ability and knowledge, as well as attitudes, internalized by the individual and acting for him as the basis for realizing the life scenario. According to G. Becker, human capital is formed by investing in people, among which training, internship in production, health care costs, migration and the search for information on prices and incomescan be mentioned. Defining the elements that make up the structure of human capital, N.A. Buranshina and N.L. Ivanova include knowledge, skills, abilities, health, cultural and moral capital and social identity in it. Knowledge, abilities, skills, in turn, are divided into professional; business; organizational, having value, and acquired only in a specific municipal entity; social, connected with socialization and interpersonal communications, for example, the ability to use the Internet, knowledge of foreign languages, the ability to drive a car, etc. (Buranshina, Ivanova, 2011). 
Most of the modern approaches to assessing human capital are based on economic calculations of the ratio of costs of maintenance and education of a migrant and his contribution to production, economic development of the industry in which he works. An approach to the study of human capital as an economic growth factor is of interest, suggesting that the leading factor in carrying out technological changes and the ability to adapt to them is education (Nelson, Phelps).

The view that the increase in labor productivity depends, first of all, on the development of the capabilities of workers and only then from the improvement of the means of production is found even in the works of A. Smith. Human capital by definition of the creator of this theory G. Becker is formed by investing in people, among which training, internship in production, health care costs, migration and the search for information on prices and incomescan be mentioned.

Most often, as indicators of the total human capital, researchers use a formally confirmed level of vocational education; number of years spent on education (including school); various additional skills (knowledge of foreign languages, ability to work on a computer, ability to learn, etc.) (Karavai, 2016:112).

Education is necessary in the process of introducing innovations, new technologies. One of the important characteristics of education throughout life is the capacity for self-education, the ability to work with information and modern mobile devices to obtain it.

P.P. Lisitsyn and A.V. Rezaev call the concept of human capital as one of the most fundamental in the study of migration, along with a network approach, a new institutional approach, a risk theory and the sociology of transnational migration (Lisitsyn, Rezaev, 2012:123).

For different studies, the concept of human capital and its components is refined.
T.I.Zaslavskaia, one of the recognized and respected authors who developed the theory of human potential in the domestic science, notes that human potential characterizes the quality of the national society as a subject of societal reproduction and development. It has a decisive influence on the viability and dynamics of society and manifests itself in the number, qualifications and activity of players, from being informed about the sociocultural context and teamwork. T.I. Zaslavskaia emphasizes the internal dynamism inherent in human potential, the capacity for self-development and includes in it such components as socio-demographic potential, social-economic potential (level and structure of employment, qualifications and professionalism, nature and conditions of work, the demand for labor and intellectual resources, indicators of the quality of life, the level of welfare and real incomes, the availability of social goods and services, the life chances of various groups and strata, guarantee of human rights and freedoms, the protection of people), the social activity potential (the state of science, higher education and culture, the peculiarities of the national mentality, the activity potential (activity, energy, business qualities of social actors, the predominance of innovative or traditional thinking and activity, the manifestation of these qualities that is additional education, learning foreign languages, mastering of knowledge-intensive information and intellectual technologies (Zaslavskaia,2003:79). All these forms of capital can be converted into economic capital in one way or another. Their potentials are interrelated and tend to be leveled. (Radaev, 2002: 29).

In modern studies of labor migration, more emphasis is being placed on the adaptation of migrants in new conditions, but the methodology for assessing human resources and human capital remains undeveloped. Regardless of the way in 
which labor resources are valued, the assessment of human capital can change in the regional dimension, since it is determined ultimately by factors such as the countries of the outcome of labor migrants and the level of their education.

\section{Statement of the problem}

The territory of the Siberian region, including the Novosibirsk region, has become increasingly attractive for labor ethnic migration in the last decade. According to the analytical reports of the FMS, which registered the arrivals and the issuance of permits for residence and employment until April 5, 2016, in 2014 more than 106 thousand foreign citizens were lawfully locatedin the Novosibirsk region, over 71 thousand people were in the first half of 2015 , over 76 thousand foreign citizens entered the border crossing points, of which more than 46 thousand were registered for migration for the first time (The report on the results and the main activities...). The main goal of the arrival of foreign citizens is to work in the region. A significant number of migrants who entered the labor market came from Central Asia (Uzbekistan, Tajikistan, Kyrgyzstan).

Unfortunately, there is not sufficient statistical data on arriving migrant workers, which would allow assessing their labor potential from different sides. Part of the problem can be solved with the help of applied sociological research, in particular based on the information approach, which allowsstudying any object on the basis of the analysis of information aspects characteristic for it.

\section{Methods: Possibilities}

for assessing labor resources

\section{and human capital of labor migration}

To assess the quality of labor migration resources, a secondary analysis of the data obtained as a result of the research Information Needs of Labor Ethnic Migrants (based on the
Example of those Arriving from Central Asia to the Novosibirsk Region) was conducted in December 2014 - January 2015 as part of the implementation of the socially significant project Novosibirsk is the Territory of an Accessible Information Environment for Labor Migrants (The report on the results and the main activities). The aim of the study was to recreate a general picture of the awareness of migrant workers about different aspects of being at the place of work (legal, social, socio-cultural) and sources of information about employment opportunities and living in Novosibirsk.

At the same time, a number of questions that were included in the questionnaire make it possible to talk about the level of education, professional skills, knowledge of native and Russian languages, the skills of obtaining information not only through informal channels, but also from Internet resources, the desire and ability to use these sources. The survey involved interviews in the places of concentrated stay of migrant workers: in the hall for servicing foreign citizens of the Federal Migration Service of the Novosibirsk Region, in enterprises working with migrant workers. The sample consisted of groups differing in citizenship, sex, age, place of residence in the homeland, knowledge of the Russian language, and the level of education. In total, 523 respondents from Central Asia countries such as Kyrgyzstan, Uzbekistan, Tajikistan of different age groups took part in the survey (Fig. 1). All participants in the study are persons of working age from 17 to 62 .

\section{Discussion}

\subsection{Some criteria for assessing human capital}

To assess the human capital of labor migrants, it is necessary to find out the stock of "working age". The distribution of respondents by age is shown in Fig. 1. 


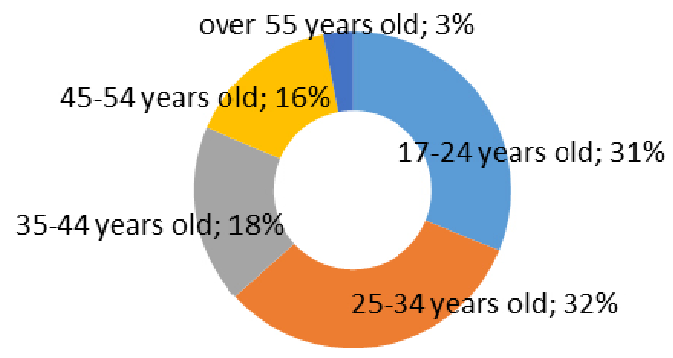

17-24 years old

25-34 years old

35-44 years old

45-54 years old

n over 55 years old

Fig. 1. Distribution of respondents by age ( $\%$ of respondents)

Migrants aged 17-34 years old, when new knowledge is quickly mastered, amounted to $63 \%$.

The second important indicator is the labor activity of migrants. $90.1 \%$ of the respondents had a job at the time of the survey; only $1.5 \%$ of the respondents studied in educational institutions; $8.2 \%$ of the respondents temporarily did not work. The main spheres of employment of the surveyed labor migrants are construction, transport, trade, services (cleaning companies, floristics), sewing and food production, housing and communal services and agriculture. These areas of employment do not imply mandatory availability of vocational education and qualifications. Only 3 people (two doctors and one entrepreneur) had a higher professional status, which was less than $0.05 \%$. The distribution of the respondents according to the level of education is shown in Fig. 2. $16 \%$ of the respondents have higher and incomplete higher education, $16 \%$ have advanced education, $60 \%$ have secondary education, and $6 \%$ have initial vocational education. At the same time, the survey identified a group of about $5 \%$ of therespondents having elementary school education or incomplete secondary education. These are young men (there are no women in this group), half of them are under the age of 28. Apparently, a rather low level of education in this group is associated with the beginning of work in positions that do not require special training and the fact that young men are forced to solve the issue of earnings earlier.

Comparing the data on the level of education provided by the study of foreign migrants on the Siberian labor market in 2008, where the educational level of migrants from Central Asia is estimated to be quite high: $21.7 \%$ had higher and incomplete higher education, $51.5 \%$ had advanced education,the remaining $26.7 \%$ had secondary education (not less than completed 10 years of education) (Soboleva, Chudaeva, 2008), we can note the comparability of the results obtained. At the same time, the emergence of the group with a low educational level, apparently, is due to the liberalization of migration policy for the past period.

The fact that more than half of those who came to work (66 \%) do not have professional training, already determines the scope of their future employment. To get a better job, investments in the education of this category of migrants will be significant.

P. Bourdieu attributed the characteristics of the social capital, which forms the habitus of its members, to the features of the social environment. In incorporated form he includes the norms, principles, views and attitudes of the individual in relation to oneself and to the world, one's knowledge, practical skills - everything that the one receives in the process of education, training and communication from the very infancy throughout life. This means that the 


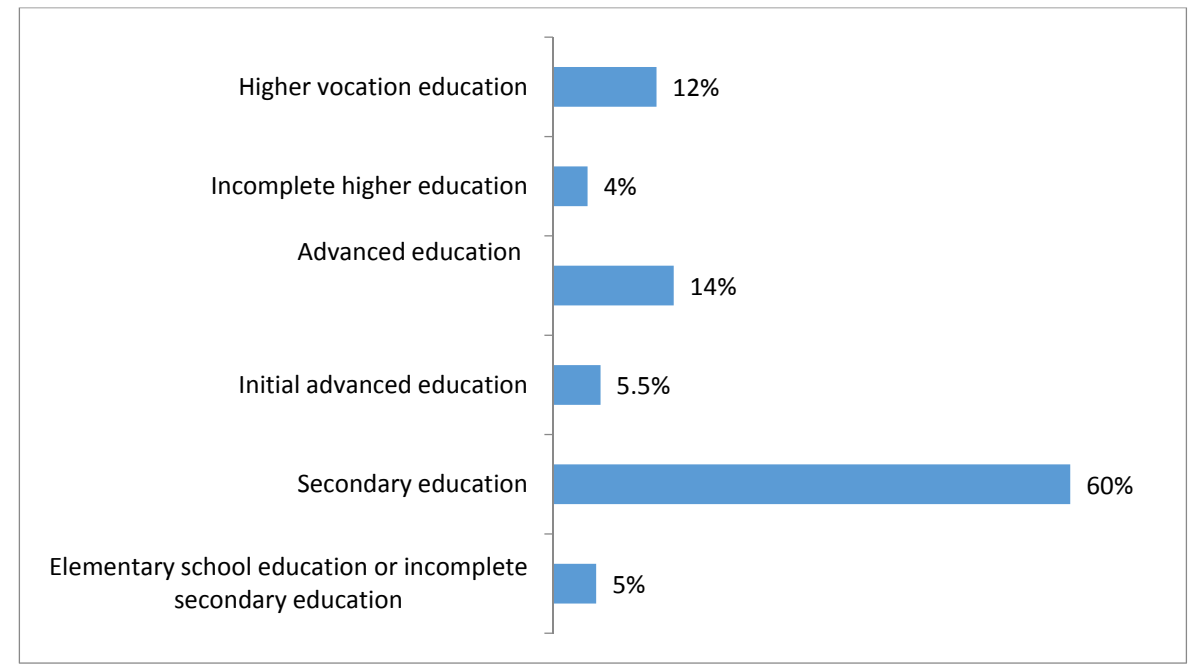

Fig. 2. Level of education of the respondents (\% of respondents)

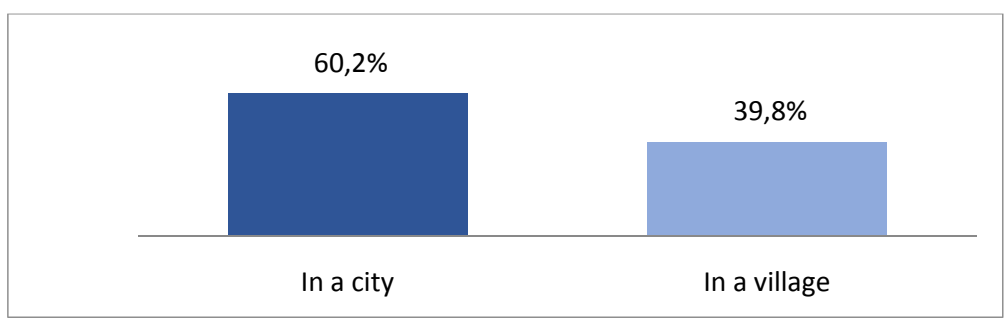

Fig. 3. Distribution of the respondents by their place of residence in their homeland ( $\%$ of respondents)

peculiarities of the conditions of socialization, which form the vital attitudes, norms and values, determine cultural capital (Karavai,2016: 110). Therefore, the type of settlement can act as an indicator that forms the cultural capital of a person. In general, $60 \%$ of the respondents were those who live in the homeland and $39.8 \%$ live in the countryside. The distribution of answers is shown in Fig. 3. A small predominance of rural residents in the sample was noted among those who came from Kyrgyzstan - $52 \%$ of the villagers and, correspondingly, $48 \%$ of the townspeople. As for arrivals from Tajikistan, on the contrary, there is a slight predominance of citizens that is $64.6 \%$.

An important aspect in assessing the quality of human capital is the mastery of the language of the host country. Answering the question "What language is easier for you to read?", almost $40 \%$ of respondents named the Russian language (it was possible to choose several answers), besides the native language (Figure 4). This fact is important for the inclusion of migrants in adaptation processes, obtaining legal and medical assistance, for employment, as well as in organizing the education of children, since the knowledge of mother or relatives of the Russian language simplifies interaction with the host community. According to the FMS, for 10 months of 2015, 38741 foreign workers who came from countries with visa-free entry procedures confirmed their knowledge of Russian. 27045 peoplerepresented PFUR certificatesout of 


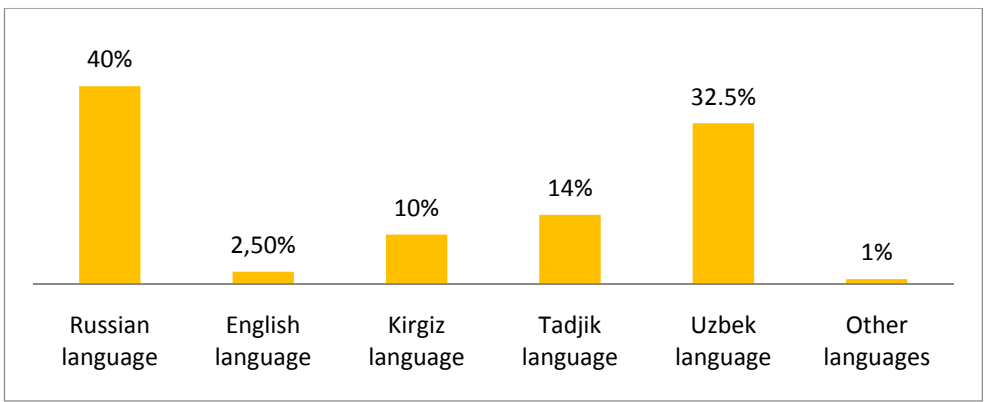

Fig. 4. Distribution of answers to the question "What language is easier for you to read?" (\% of responses)

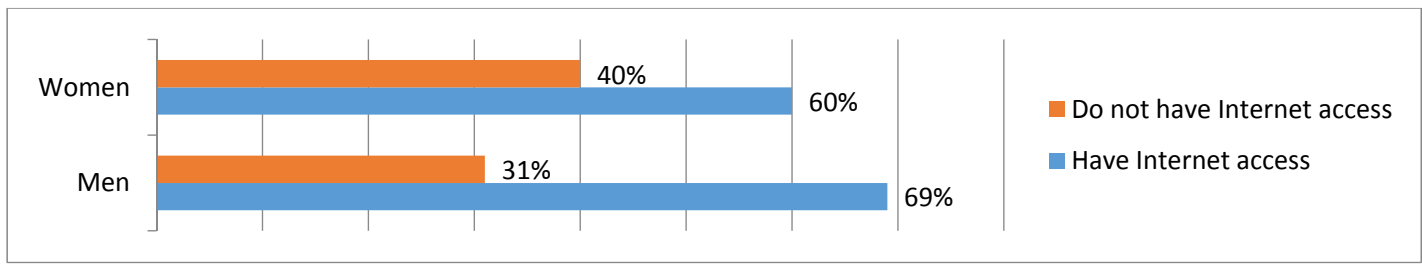

Fig. 5. Distribution of answers to the question"Do you have access to the Internet?" (\% of respondents)

the total number of those who confirmed the Russian language proficiency (Population).

One of the indicators that can characterize the human capital of migration is awareness. "Usually, awareness facilitates the process of finding a workplace. It has been proved that more educated people are generally better informed about employment and accommodation in the areas of migration, which significantly reduces the degree of uncertainty associated with migration for them. However, migrants still find themselves in a less favorable position than local residents, because they often have to obtain information about labor, housing and consumer goods markets that local residents already possess"(Moiseenko, Chudinovskikh, 2000: 128). Filling in the information gap makes the behavior of migrants more economically efficient. Such an opportunity will be higher if the migrant speaks language of the host society, is aware of the information technologies providing information on legal issues of stay and employment, offers on the labor market, prices for food, goods and services, etc. Indirect indicators of awareness can be knowledge of the Russian language, the availability of access to the Internet, as well as awareness of the living conditions in the region of residence.

When asked about the availability of Internet access, $63.5 \%$ answered affirmatively, another $3.3 \%$ answered sometimes they can get it. $31.7 \%$ of respondents do not have Internet access. In $52.2 \%$ of cases, access to the network occurs from a mobile phone, $34.2 \%$ use the Internet from a home computer or tablet, and $4.9 \%$ from a computer at work. Men have access to the Internet a little more (69 \%) than women $(60 \%)$.

The possibility of using the Internet among respondents in the group of 17-24 years old people is $81 \%$, among respondents aged $25-40$ years old it is $71.4 \%$ of respondents, and in the group older than 41 years old, access to the network is reduced, only $32.8 \%$ of respondents have access.

In the course of the survey, respondents were asked about the awareness about the 


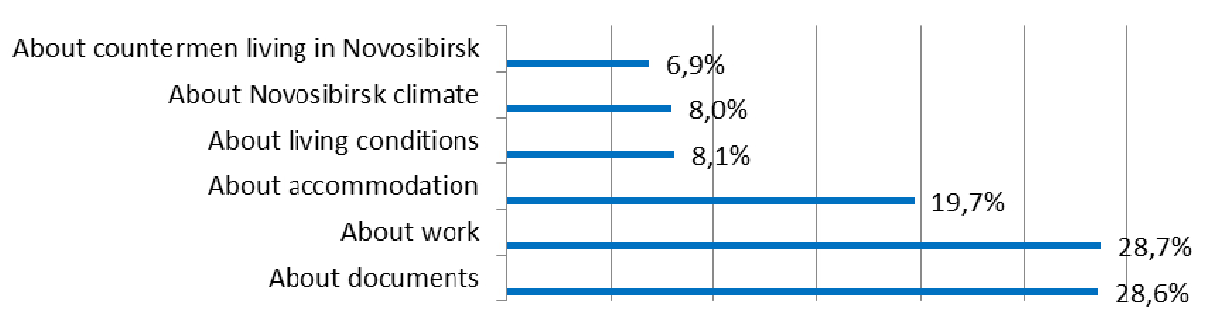

Fig. 6. Distribution of answers to the question "When preparing for a trip to Novosibirsk, did you look for information about ...? (You can choose several answers, $\%$ of answers)

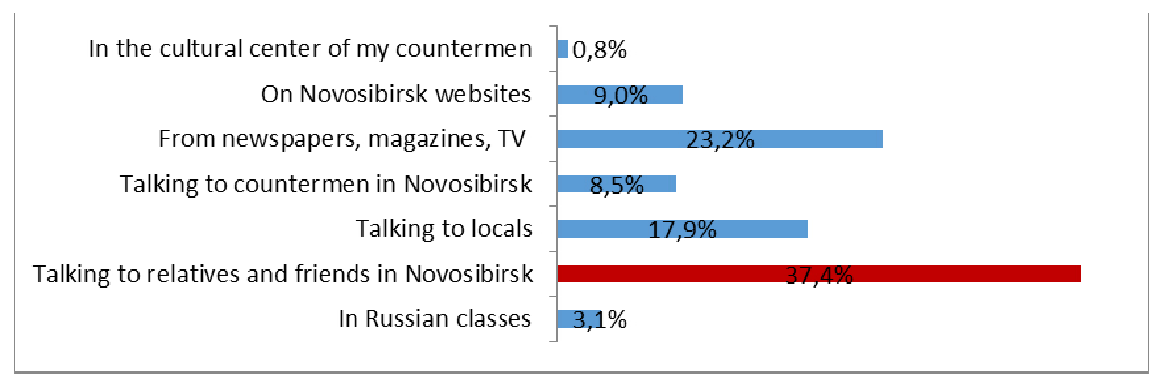

Fig. 7. Distribution of answers to the question "Sources that you are now using to obtain information about life in Novosibirsk ..." (you can choose several answers, $\%$ of answers)

place of stay, the information they received before departure, its content, sufficiency, and information that they needed after their arrival (Fig. 6), as well as the sources they contacted and are contacting to obtain information about the place of migration.

$80.1 \%$ of the respondents named relatives and acquaintances that already live in Novosibirsk as the preferred information source aboutthe place of migration. Another $9.3 \%$ turned to the search for information on the Internet, $3.9 \%$ used information on specialized sites.

Subjective assessment of the sufficiency of information necessary to adapt to a new location is quite high. Only about $20 \%$ of respondents expressed the opinion that the information they had was insufficient, which indirectly confirms the formation of diaspora networks in which migration services are provided on different terms (free of charge and/or commercial).
As before departure, and on the spot,familiar and relativesremain the main sources of information about the migration region. None of other official or unofficial sources can compete with them. About $40 \%$ of the respondents turned to friends or relatives in search of information about work, accommodation, services in Novosibirsk. This shows that the problem of social networks as the main source of information and interactions is acute. The creation of enclaves, ghettoisation or the formation of "invisible ghettos" hampers social and cultural adaptation, increases "migratory risks" and insecurity of migrants (Tiuriukanova, 2008).

Thus, migrant workers arriving from Central Asia have a sufficient "stock" of working age, but they can be employed, mainly, in posts involving more unskilled labor, as they do not have sufficient level of education. At the same time, most of them could engage in self- 
education with the help of network resources, especially in the field of studying the Russian language.

\subsection{General problems in assessing the quality of the human capital of labor migration}

Despite the fact that the migration contingent differs in some regions of the country, there are general trends and problems in the evaluation and application of labor resources of migrants and their human capital.

Inflows of foreign migrants to Russia have ambiguous significance for the host community. On the one hand, the aging of the population requires an influx of the able-bodied population from outside, as the population of Russia is projected to have decreased from 142 million in 2012 (Population) to 139 million peopleby 2030, while the elderly population, that is people above 65 years of age, will account for more than a third of the total population (Estimated number...). On the other hand, to develop an innovative, competitive economy, to implement the strategic project Innovative Russia - 2020, we need a human resource characterized by professionalism, competence, and the ability to learn quickly throughout life (Innovative Russia - 2020, 2010). Thus, there is a contradiction between the quality of professionalism of arriving migrants and the requirements of innovative development of Russian society, since the majority of arriving migrant workers do not have the necessary set of competencies to create an innovative product for the international market.

The second contradiction is that any actively developing country tries to reserve the right to skilled labor, and migrants are asked to fill the niches of a low-skilled labor market. Part of the labor migrants are ready for such conditions with the aim of further stay in the country, obtaining citizenship, registering a Russian pension that far exceeds the amount of pensions in their home countries. But, how long is the migrant willing to work on the proposed conditions? It is quite difficult to make an economic forecast of filling the market with unskilled labor. How beneficial is this unskilled labor for the host community?

Detailed economic calculations have not yet been proposed either in Russia or in Western Europe, although in these countries there is an active debate between economists, especially on the question of how reliable the statistical calculations of the "profitability" of migrants' stay in the country are. Economists also come to opposite conclusions.

Firstly, there is currently no complete picture of the costs of the social sphere for migrants, and therefore the calculation of the cost per capita of a migrant is not accurate (Rickens). Secondly, the balance of the migrant's budget will be in the red if the total costs of the state, such as defense, infrastructure, legal system, policespending, etc., are included in his calculations. As for Germany, for example, migration is currently a loss for the state budget and social sphere (Sinn, 2015).

To implement such projects, investments of the states of the host community are necessary. And if in some countries of North and West Europe the governments of the countries are ready to invest educational projects for migrants, in Russia this issue remains unresolved, which is noted in a number of works by Russian scientists (About 400,000 jobs...). Since there is ambiguity in assessing the need for labor migration resources for the development of individual territories, it is rather difficult to develop a concept of differentiation of the potential of labor migrants in order to optimize the management of labor migration flows.

\section{Conclusion}

1. Since there is ambiguity in assessing the need for labor migration resources for the 
development of individual territories, it is difficult to develop a concept of differentiating the potential of labor migrants with the aim of optimizing the management of labor migration flows.

2. The task of reducing the risk of costs for migrants exceeding their contribution to the development of the region could be solved with the introduction of a planned system for the reception of migrants and the issuance of work visas if thereis a place of work and an invitationfrom the organization on the territory of the region that is ready to accept migrants on a contract basis and substantiating the need to employ citizens from other countries.

3. When calculating the costs of information support for migrants, it is necessary to take into account their age characteristics and not $100 \%$ ability to work with network resources, especially for women.

4. The development of human capital remains one of the important tasks. If young people who have a high level of education leave the country, while people with a low level of education and professional competencies come to work, the country's innovative potential will be difficult to develop. The general cultural level of the population will also decline. The hope that a low-skilled labor of migrants with low wages will be able to provide a decent standard of living for a third of the population of the country that has a retirement age is practical.

5. The main programs should be programs to promote the Russian language to a sufficiently high level.

6. When developing educational professional programs for migrants, first of all, the needs of the region should be taken into account. The second important point should be the selection of migrants for training in such programs. Particular attention in training should be paid to women, their abilities and skills to work with information, mobile devices to obtain information from open access network resources.

\section{References}

Anokhina, N.F., Perevalova, K.S. (2013). Rol' Rossii v mezhdunarodnoi trudovoi migratsii [The role of Russia in international labour migration], InProblemy i perspektivy ekonomiki $i$ upravleniia: materialy II mezhdunarodnoi nauchnoi konferetsii (Sankt-Peterburg, iiun' 2013) [Proc. of the II International Scientific Conference (Saint-Petersburg, June 2013)]. SaintPetersburg, 38-40.

Beishenaly, N.E., Pereboev, V.S. (2013). Vstuplenie Kyrgyzstana v Tamozhennyi soiuz i edinoe ekonomicheskoe prostranstvo: posledstviia dlia rynka truda i chelovecheskogo kapitala [The accession of Kyrgyzstan to the Customs Union and the common economic space: implications for labor market and human capital], InEvraziiskaia ekonomicheskaia integratsiia [Eurasian economic integration], 3(20), 83.

Buranshina, N.A., Ivanova N.L. (2011). Human Capital of a Municipal Entity: Notion and Structure, In Vestnik Ural'skoi akademii upravleniia[Bulletin of Ural State University]. Available at: http://vestnik.uapa.ru/en/issue/2011/04/24/(accessed 12.11.2016).

Cube Christian. Immigration und Arbeitskaempfe in den USA. Available at:https://publishup.unipotsdam.de/opus4-ubp/files/2752/wtthesis03.pdf

Grantovoe soglashenie Ministerstva regional'nogo razvitiia Novosibirskoi oblasti № 49[Grant agreement of the Ministry of regional development of the Novosibirsk region No. 49].

Doklad o rezul'tatakh i osnovnykh napravleniiakh deiatel'nosti UFMS Rossii po Novosibirskoi oblasti na 2014 g. iplanovyi period 2015-2017 gg.[The report on the results and the main activities 
of the Office of the Federal Migration Service of Russia on the Novosibirsk region for 2014 and the planning period of 2015-2017](2015).Novosibirsk, 1-30. Available at: http://fms-nso.ru/ufms/static/ Plan \%20i \%20prognoz (accessed 05.2015).

Innovatsionnaia Rossiia - 2020 (Strategiia Razvitiia Rossiiskoi Federatsii na period do 2020 goda) [Innovative Russia - 2020 (Strategy of development of the Russian Federation for the period until 2020)] (2010). Moscow, Russian Ministry of Economic Development, 105p.Available at: http:// datis.pro/upload/aed/Innovative-Russia-2020.pdf (accessed 08.11.2016).

Karavai, A.V. (2016). Chelovecheskii kapital potomstvennykh rossiiskikh rabochikh [Human capital of hereditary Russian workers], In Monitoring obshchestvennogo mneniia [Monitoring of public opinion], 6 (136), 107-125.

Kuz'minov, Ya.I., Ovcharova, L.N., Iakobson, L.I., red. (2016). Chelovecheskii kapital kak faktor sotsial'no-ekonomicheskogo razvitiia. Kratkaia versiia doklada [Human capital as a factor of socio-economic development. The short version of the report]. XVII Apr. mezhdunar. nauch. konf. po problemam razvitiia ekonomiki i obshchestva, [XVII April International Scientific Conference on development of economy and society],Moskow, 19-22 of April, Izdatel'skii dom Vysshei shkoly ekonomiki.

Lisitsyn, P.P., Rezaev, A.V. (2012). Teoretiko-metodologicheskie osnovaniia sotsial'nogo analiza protsessov trudovoi migratsii [Theoretical and methodological foundations of social analysis of labour migration processes], InVestnik SPbGU [Bulletinof the State University of Saint-Petersburg], 12 (4), 122-129.

Moiseenko, V.M., Chudinovskikh, O.S. (2000). Teoriia chelovecheskogo kapitala i issledovaniia migratsionnykh protsessov v Rossii [Human capital theory and migration studies in Russia],InProblemy prognozirovaniia [Problems of forecasting], 4, 124-137.

Mukomel', V.I. (2011). Integratsiia migrantov: vyzovy, politika, sotsial'nye praktiki [Integration of migrants: challenges, policies, social practices], In Mir Rossii [World of Russia], 1, 34-50.

Naselenie, uchtennoe pri Vserossiiskoi perepisi naseleniia 2010 goda [The population included in the population census of 2010]. Available at: http://www.gks.ru/free_doc/new_site/perepis2010/croc/ Documents/Vol1/pub-01-01_02.pdf(accessed 05.11.2016).

Nesterov, L., Ashirova, G. (2003). Natsional'noe bogatstvo i chelovecheskii kapital [National wealth and human capital],In Voprosy ekonomiki [Economic issues], 2, 17.

Nelson, R., Phelps, E. Investment in humans, technological diffusion, and economic growth,69-75.

Okolo 400 tysiach rabochikh mest sozdadut dlia vernuvshihsia v Uzbekistan migrantov [About 400 thousand workplaces will be created for the migrants who came back to Uzbekistan], In Demoskop Weekly [Demoscope Weekly], 2014, 621-622. Available at: http://demoscope.ru/weekly/2014/0621/ panorm01.php (accessed 14.06.2015).

Peter, E. Gehirne auf Wanderung. Available at: http://www.taz.de/!5204128/ (accessed 08.11.2016).

Pitukhina, M.A., Sigova, S.V. (2013). Vliianie zarubezhnoi trudovoi migratsii na kachestvo chelovecheskogo kapitala $\mathrm{v}$ Rossii [The impact of foreign labor migration on the quality of human capital in Russia], InVestnik Leningradskogo gosudarstvennogo universiteta im. A.S. Pushkina[Bulletin of Pushkin Leningrad State University], 1 (6), 14-21. 
Posledstviia vstupleniia Kyrgyzstana v Tamozhennyi soiuz i EEP dlia rynka truda ichelovecheskogo kapitala strany [Consequences of the accession of Kyrgyzstan to the Customs Union and common economic space for the labor market and human capital of the country] (2013). Saint-Petersburg, 122p. Available at: http://www.eabr.Org /general//upload/CII \%20- \%20izdania/Proekti \%20i \%20dokladi/ Kyrgyzstan \%20- \%20CU/EDB_Centre_Report_13_Full_Rus_1.pdf (accessed 12.11.2016).

Predpolagaemaia chislennost' do 2030 goda: statisticheskii biulleten'.50 [The estimated number for 2030: statistical Bulletin](2010). Moscow, Federal'naia sluzhba gosudarstvennoi statistiki, 5-225.

Radaev, V.V. (2002). Poniatie kapitala, formy kapitalov i ikh konvertatsiia [The concept of capital, forms of capitals and their conversion], In Ekonomicheskaia sotsiologiia [Economic Sociology], 3(4), 20-34. Available at: https://ecsoc.hse.ru/archive.html (accessed 30.01.2017)

Rickens, Christian. Hans-Werner Sinn über Einwanderer: „Ich vermute per Saldo immer noch einen großen Gewinn". Available at: http://www.spiegel.de/wirtschaft/soziales/interview-hans-wernersinnmigration-bringt-deutschland-gewinn-a-1011147.html (accessed 08.11.2016).

Sebald, Christoph. Arbeitsmigration in der EU - eine Kritik.Available at: http://www. treffpunkteuropa.de/Arbeitsmigration-in-der-EU-eine-Kritik,05069 (accessed 08.11.2016).

Sinn, Hans-Werner. (2015). Zuwanderer in DeutschlandMigration: Gut für den Arbeitsmarkt, schlecht für den Staa,. In Wirtschaftswoche, 10. Februar 2015. Available at: http://www.wiwo.de/ politik/deutschland/zuwanderer-in-deutschlandmigration-gut-fuer-den-arbeitsmarkt-schlecht-fuerden-staat/11339866.html (accessed 10.11.2016).

Soboleva, S.V., Chudaeva, O.V. (2008). Inostrannye migranty na sibirskom rynke truda: chelovecheskii kapital immigratsii [Foreign migrants on the Siberian labour market: human capital immigration], In Vestnik Novosibirskogo gosudarstvennogo universiteta ekonomiki i upravleniia [Bulletin of the Novosibirsk State University of Economics and Management], 1.

Tiuriukanova, E. (21.01.2008).Trudovaia migratsiia v Rossiiu [Labor migration in Russia], InElektronnaia versiia biulletenia «Naselenie i obshchestvo» [The electronic version of the Bulletin "Population and society"]. Available at: http://polit.ru/ article/ 2008/01/21/ demoscope315/ (accessed 5.02.2017)

Zaslavskaia, T.I. (2003). Chelovecheskii potentsial kak faktor zhiznesposobnosti obshchestva [Human potential as a factor of viability of society], In Rossiia, kotoruiu my obretaem/ Otv. red. T.I. Zaslavskaia, Z.I. Kalugina [Russia, we gain. Ed. by T.I. Zaslavskaia, Z.I. Kalugina]. Novosibirsk, Nauka, 73-82. 


\title{
Опыт оценки человеческого капитала
}

\author{
трудовой этнической миграции \\ (на материале исследования НСО)
}

\author{
Н.Л. Микиденко, \\ Т.И. Монастырская, С.П. Сторожева \\ Сибирский государственный университет \\ телекоммуникацчий и информатики \\ Россия, 630102, Новосибирск, ул. Кирова, 86
}

\begin{abstract}
Необходимость оценки потенцฺиала трудовой миграциии вызвана проблемами эффективного управления входящчим миграционными потоками. Регион, принимающчий трудовых мигрантов, должен ориентироваться в формировании своей миграционной концепции на собственные экономические задачи и потребности. В работах российских и зарубежных ученых даются противоречивые оценки миграционных процессов, что связано с отсутствием оптимальной модели расчета экономической цуелесообразности инвестирования в прибывающих на территорию региона трудовых мигрантов, а также модели оценки их человеческого капитала (культурного и соичильного). Один из возможных способов такой оценки может базироваться на результатах анализа информационных потребностей мигрантов. Исследование трудовых этнических мигрантов стран среднеазиатского региона, проведенное в Новосибирской области, ориентированное на выявление сущчности и структуры информационных потребностей трудовых мигрантов, представляет собой попытку оценки их потенциала в аспекте человеческого капитала. Информированность рассматривается как один из элементов человеческого капитала, который может конвертироваться в экономический, сокрашая время и денежнье затраты, период оформления документов, поиска жилья и трудоустройства. Информированность анализируется в аспекте субъективной оценки достаточности информации, владения современными информацчионылми услугами и сервисами, возможности доступа к сети Интернет, а также наиболее востребованным источникам при получении информации на родине о месте пребывания и по прибытии в регион.
\end{abstract}

Ключевые слова: трудовая миграция, этническая миграции, человеческий капитал, управление миграцией, принимающее сообщество, информированность.

Научная специальность: 24.00.00 - культурология. 